\title{
Soil and forest productivity: a case study from Stone pine (Pinus pinea L.) stands in Calabria (southern Italy)
}

\author{
Bravo $F^{(1)}$, Lucà $M^{(2)}$, Mercurio $R^{(2)}$, Sidari $M^{(2)}$, Muscolo A ${ }^{(2)}$
}

The objective of this study was to determine whether edaphic and/or topographic variables may be used as predictors of site productivity in Stone pine stands in Calabria (southern Italy). To accomplish this goal, a linear discriminant rule was developed using data from 16 pure Stone pine stands, grouped into three different classes based on the mean dominant height annual growth. The discriminant rule was based on three linear models (one for each class) that jointly predicts site class for a given stand. To test the accuracy of the proposed method, cross-validation was carried out by developing 16 alternative discriminant rules (excluding the analyzed data). Predictors tested were edaphic (texture, $\mathrm{pH}$, organic matter) and topographic (altitude and slope) variables. The model obtained allow to discriminate poorest sites accurately $(100 \%$ of sites were correctly re-classified using the discriminant functions obtained). In more productive areas, sites were correctly re-classified in the $33.33 \%$ of cases, while in intermediate sites the correct classification was equal to $50 \%$. Our discriminant rule classifies correctly the poorest stands, suggesting that site index in plain site soils strongly depends on clay percentage. Overall, the edaphic model obtained classifies plots into the correct site index class $61.11 \%$ of cases, which is considered an acceptable value for these kinds of studies.

Keywords: Clay, Pinus pinea, Site index, Site productivity, Topographic factor

\section{Introduction}

Stone pine (Pinus pinea L.) is one of the most important species in southern Europe widely distributed along Mediterranean coastal areas, from Portugal to Syria. Stone pine has important ecological, landscape, recreation and soil conservation uses covering over 600 thousand hectare mainly in Spain, Italy, Portugal, France, Morocco and Tunisia. In Italy the main products are pine nuts, wood and truffles. However, both soilsite and local studies focused on plantations are scarce. Young planted stands in southern

(1) Sustainable Forest Management Research Institute, University of ValladolidINIA, avda. de Madrid 57, E-34004 Palencia (Spain); (2) Department of Agricultural and Forest Systems Management, Faculty of Agriculture, University "Mediterranea" (Italy)

\section{@, Felipe Bravo (fbravo@pvs.uva.es)}

Received: May 03, 2010 - Accepted: Dec 17, 2010

Citation: Bravo $F$, Lucà $M$, Mercurio R, Sidari $M$, Muscolo A, 2011. Soil and forest productivity: a case study from Stone pine (Pinus pinea L.) stands in Calabria (southern Italy). iForest 4: 25-30 [online: 2011-01-27] URL: http://www.sisef.it/iforest/show.php? id $=559$
Italy need silvicultural treatment in order to achieve managerial objectives (mainly environmental protection and production), to avoid permanent productivity declines.

Site index, defined as a species-specific measure of actual or potential forest productivity (Helms 1998), has been widely used as forest productivity surrogate because it is an important parameter in forest growth and yield modeling. Site index can be estimated through site data, stand data, or both combined. Usually, in operational forestry, site index is estimated by measuring stand variables (dominant height and age). However, in some cases (young stands, highgraded stands, etc.) appropriate stand variables are not available. Studies based on soil-growth relationship (soil-site method) have been carried on for a wide range of species elsewhere (e.g., Harding et al. 1985, Jokela et al. 1988, Monserud et al. 1990, Pacheco 1991, Wang 1995, Bravo \& Montero 2001), but very few soil-site studies have been reported for Stone pine (Bravo-Oviedo \& Montero 2005). Site index is a variable surrogate of the net stem growth that can be harvested in traditional forestry. As net stem growth harvested is roughly a $10 \%$ of the Gross Primary production (GPP) in the temperate forests (Pretzsch 2009), site index serves also as proxy of GPP linking forest growth and yield science with produc- tion ecology. Site index perform better in monospecific, even aged, single-layered forests and plantations as young planted Stone pine stands.

Soil-site studies based on topographic and edaphic factors are utilized to estimate site index when stand data as dominant height and age are not available or not suitable for this purpose. Altitude, slope, aspect (Jokela et al. 1988, Pacheco 1991, Holmgren 1994) and geographic position (Pacheco 1991) are the topographic factors commonly used (Jokelaet al. 1988, Pacheco 1991, Holmgren 1994) to estimate site index. It is common knowledge that topography, in the forest ecosystem, influences local microclimates by changing the pattern of precipitation, temperature and relative humidity (Tsui et al. 2004, Yimer et al. 2006) and significantly affects soil physical and chemical characteristics and soil organic matter trend, strictly related to the dynamic and ecology of the soils.

Topographic factors are usually utilized in combination with edaphic factors. Soil texture and nutrients levels are commonly used to estimate site index (Baker \& Broadfoot 1979, Jokela et al. 1988, Turner et al. 1990, Pacheco 1991), though the wide range of nutrients and analytical methods make difficult to compare the results. On the other hand, it is well known that nutrients explain a low percentage of height increment (Baker \& Broadfoot 1979). For this reason, some authors avoid the use of nutrients to estimate site index (Steinbrenner 1976). As multicollinearity among soil properties related to site index can also cause problems in regression analysis (McQuilkin 1976, Verbyla 1986), discriminant analysis (Harding et al. 1985, Bravo \& Montero 2001, Bravo-Oviedo \& Montero 2005) have been used.

Many conceptual models exist for defining the biotic, abiotic, and cultural practices that influence forest productivity (Switzer 1978, Burger 1994, Morris \& Miller 1994). Morris \& Miller (1994) described forest productivity as a function of plant potential, climate, soil-site quality, and catastrophes. Computer modelling has been used to account for these factors, but models are imperfect and sometimes unsatisfying, because of scaling issues (Proe et al. 1994).The ability to make a compelling field evaluation of soil properties and site productivity would be an important achievement.

The objective of this study is to determine if edaphic and/or topographic variables can be used as predictors of site productivity in Stone pine stands in Calabria (southern Italy). To accomplish this objective, a discriminant rule was developed by using data from 16 pure Stone pine stands. Three site productivity classes have been developed 
Fig. 1 - Walter-Lieth climate diagram and location map showing plots situation in Castrovillari, Calabria Apennine, southern Italy (Lat $39^{\circ} 50^{\prime}-53^{\prime}$ 'Long $15^{\circ} 55^{\prime}-16^{\circ} 16^{\prime}$ ). The natural vegetation is dominated by Holm oak (Quercus ilex L.) and Hop hornbeam (Ostrya carpinifolia Scop.), sharing dominance with other broadleaves.

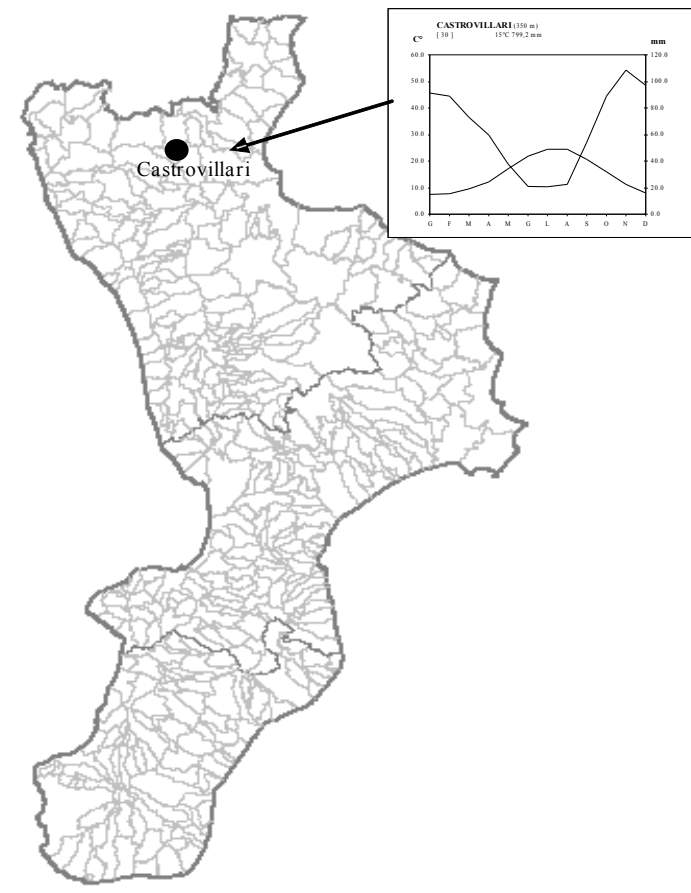

Tab. 1 - Main edaphic, topographic and soil site characteristics of Stone pine plots analyzed to study site index estimation in Calabria (southern Italy).

\begin{tabular}{|c|c|c|c|c|c|}
\hline Plot & Age & $\begin{array}{l}\text { Altitude } \\
\text { (m.a.s.l.) }\end{array}$ & Aspect & Parent material & Soil type \\
\hline \multicolumn{6}{|c|}{ Castrovillari } \\
\hline CA1 & 45 & 700 & W & Calcareous breccias & Pachic Hapludolls \\
\hline CA2 & 45 & 680 & $\mathrm{~W}$ & Calcareous breccias & Pachic Hapludolls \\
\hline CA3 & 45 & 600 & SW & Calcareous breccias & Pachic Hapludolls \\
\hline CA4 & 45 & 500 & SW & Calcareous breccias & Pachic Hapludolls \\
\hline \multicolumn{6}{|c|}{ Frascineto } \\
\hline FR1 & 55 & 420 & SW & Dolomite & Pachic Hapludolls \\
\hline \multicolumn{6}{|c|}{ Morano } \\
\hline MO1 & 35 & 800 & W & Dolomite & Pachic Hapludolls \\
\hline $\mathrm{MO} 2$ & 35 & 840 & $\mathrm{~W}$ & Dolomite & Pachic Hapludolls \\
\hline MO3 & 36 & 820 & $\mathrm{~W}$ & Dolomite & Pachic Hapludolls \\
\hline MO4 & 36 & 820 & $\mathrm{~W}$ & Dolomite & Pachic Hapludolls \\
\hline MO5 & 36 & 840 & $\mathrm{~W}$ & Dolomite & Pachic Hapludolls \\
\hline \multicolumn{6}{|c|}{ Papasidero } \\
\hline PA1 & 40 & 360 & $\mathrm{NE}$ & Calcareous Dolomite & Pachic Hapludolls \\
\hline PA2 & 38 & 460 & $\mathrm{NE}$ & Calcareous Dolomite & Typic Hapludolls \\
\hline PA3 & 38 & 485 & $\mathrm{NE}$ & Calcareous Dolomite & Typic Hapludolls \\
\hline PA4 & 38 & 485 & $\mathrm{NE}$ & Calcareous Dolomite & Typic Hapludolls \\
\hline PA5 & 40 & 530 & SW & Calcareous Dolomite & Typic Hapludolls \\
\hline PA6 & 40 & 490 & $\mathrm{~S}$ & Calcareous Dolomite & Lithic Hapludolls \\
\hline
\end{tabular}

Tab. 2 - Stand level characteristics of Stone pine plots analyzed to study site index estima tion in Calabria (southern Italy). QMD: quadratic mean diameter; $\mathrm{H}_{0}$ : dominant height; MDHG: mean dominant height annual growth.

\begin{tabular}{lcccccc}
\hline Parameters & $\begin{array}{c}\text { Basal area } \\
\left(\mathbf{m}^{\mathbf{2}} / \mathbf{h a}\right)\end{array}$ & $\begin{array}{c}\text { Volume } \\
\left(\mathbf{m}^{\mathbf{3}} / \mathbf{h a}\right)\end{array}$ & $\begin{array}{c}\mathbf{N} \\
(\text { trees/ha) }\end{array}$ & $\begin{array}{c}\text { QMD } \\
\mathbf{( c m )}\end{array}$ & $\begin{array}{c}\mathbf{H}_{\mathbf{0}} \\
\mathbf{( m )}\end{array}$ & $\begin{array}{c}\text { MDGH } \\
\mathbf{( m )}\end{array}$ \\
\hline Mean & 21.3 & 116.3 & 612.7 & 20.9 & 8.8 & 0.22 \\
Maximum & 44.6 & 315.8 & 877 & 27.7 & 12 & 0.27 \\
Minimum & 10.1 & 45 & 353 & 17 & 5.2 & 0.04 \\
Standard deviation & 8.7 & 63 & 158 & 3.2 & 1.5 & 0.12 \\
\hline
\end{tabular}

based upon mean dominant height annual growth and the discriminant functions included both edaphic and topographic variables.

\section{Materials and methods}

\section{Site description}

The study area is located in the Calabrian Apennines, southern Italy, Lat $39^{\circ} 50^{\prime}-53^{\prime}$ Long $15^{\circ} 55^{\prime}-16^{\circ} 16^{\prime}$ (Fig. 1). Mean annual temperature is $15^{\circ} \mathrm{C}$, mean temperature of the coldest month is $7.4{ }^{\circ} \mathrm{C}$, and mean temperature of the warmest month is $24.6^{\circ} \mathrm{C}$. Mean annual precipitation is $799 \mathrm{~mm}$; summer precipitation is $102 \mathrm{~mm}$, with a dry period of 46 days. The natural vegetation is dominated by Holm oak (Quercus ilex L.) and Hop hornbeam (Ostrya carpinifolia Scop.), sharing dominance with other broadleaves.

To represent the silvicultural variability of the area studied, 16 circular plots of $706 \mathrm{~m}^{2}$ (Tab. 1) were randomly established in four different areas reforested during 1948-1970 in Calabria. In sloping terrain soil preparation was carried out in small terraces and direct seeding was done in late summer. Terrace length varied from 1500 to 2500 linear meters per hectare, with a distance between them of about 4 meters. In these stands precommercial and commercial thinning operations rarely have been executed. The canopy cover ranges from 85 up to $100 \%$. Tab. 2 and Tab. 3 show the main characteristics of the plots analyzed.

\section{Soil samples}

Soil samples (0-10 cm depth) were used to describe the characteristic of forest soils in accordance with the methodology proposed by Jokela et al. (1988), particularly because the changes caused by environmental or topographic factors are more prominent and relevant (e.g., on organic matter and soil biochemical properties) on the upper layer of the soils.

Soil samples were taken from the first 10 $\mathrm{cm}$ for each soil profile and analyzed independently. The samples were brought to the laboratory on the same day and kept in the refrigerator at $4{ }^{\circ} \mathrm{C}$ for up to $24 \mathrm{~h}$ until processing. Prior to soil analysis, all the samples were air-dried, sieved $(<2 \mathrm{~mm})$, and visible roots were removed. Particle size analysis was carried out by the hydrometer method, using sodium hexametaphosphate as a dispersant (Bouyoucos 1962); pH was measured in distilled water and $1 \mathrm{M} \mathrm{KCl}$ using a 1:2.5 (soil:water) suspension; organic carbon was determined by dichromate oxidation (Walkley \& Black 1934), and it was converted to organic matter by multiplying the percentage of carbon by 1.72 . Soil total nitrogen was measured by the Kjeldahl method (Kjeldalh 1883), and cation ex- 
change capacity (CEC) was measured using the barium chloride-triethanolamine method (Mehlich 1953). Available P was determined by the Bray II method (Bray \& Kurtz 1945). Exchangeable $\mathrm{K}^{+}$was extracted with $1 M$ $\mathrm{NH}_{4} \mathrm{OAc}$, and determined using a flame photometer. Electrical conductivity (mmhos/cm) was measured using the solution extracted from a saturated paste (Jackson 1958). Exchangeable cations $\mathrm{Ca}^{2+}, \mathrm{Mg}^{2+}, \mathrm{K}^{+}$and $\mathrm{Na}^{+}$ were extracted with $1 \mathrm{M}$ ammonium acetate $(\mathrm{pH}=7)$ and determined by atomic absorption spectrometer.

\section{Data analysis}

\section{Site productivity classes}

Three site productivity classes have been developed based upon mean dominant height annual growth (MDHG). Stands age range from 35 to 45 years. Class I was defined when MDHG is equal to or more than 0.25 meters, class II was defined when MDHG is less than 0.25 meters and over 0.19 meters and class III was defined when MDHG is equal to or less than 0.19 meters.

\section{Discriminant models}

The examined discriminant functions include edaphic and topographic variables, with the following general structure (eqn. 1):

$$
\beta_{0}+\sum_{i=1}^{n} \beta_{i} \cdot X_{i}
$$

where $\beta_{0}, \beta_{1}, \ldots, \beta_{\mathrm{n}}$ are the obtained coefficients, $X_{\mathrm{i}} \mathrm{s}$ are values of the $n$ variables used as predictors.

To obtain site index classification by using soil and topographic variables, classificatory discriminant analysis was applied. The original data set has been used to both define and validate the discriminant functions. The use of the same data set to obtain and validate discriminant models involves a bias in site misclassification, called apparent error rate, and generates an "optimistic" estimate of the accuracy of the method. To minimize the above bias, cross-validation was carried out using a discriminant function computed from all other observations to classify each observation (see Johnson 1998 - pp. 217-285 for more details).

Departure from normal distribution of the independent variables considered was verified by the Shapiro-Wilk test, and Pearson's correlation coefficients among variables were calculated. Different transformations of the original variables have been applied to avoid skewed distributions of the variables considered. To this purpose, CORR, DISCRIM and UNIVARIATE procedures of the SAS ${ }^{\circledR}$ Statistical Package were used.

\section{Results}

Tab. 3 summarizes the physical and chemical properties of the soils analyzed in this study. Soils differed mainly in soil texture
Tab. 3 - Chemical and physical soil properties (clay, sand and silt content, organic matter amount, $\mathrm{pH}$, cation exchangeable capacity, and calcium amount) and topographic variables (altitude, slope, and depth) used to develop the discriminant rule to estimate the site index class in Stone pine (Pinus pinea) in Castrovillari (Calabrian Apennines, southern Italy).

\begin{tabular}{lcccc}
\hline \multicolumn{1}{c}{ Variable } & Mean & STD & Max & Min \\
\hline Sand (\%) & 56.75 & 19.94 & 74 & 23 \\
Silt (\%) & 32.69 & 22.74 & 68 & 11 \\
Clay (\%) & 10.56 & 3.86 & 19 & 6 \\
Ca (meq/100g) & 37.63 & 13.24 & 50 & 10 \\
Organic Matter (\%) & 4.3 & 0.19 & 4.57 & 4.07 \\
Depth (cm) & 75.08 & 10.08 & 95 & 60 \\
Slope (\%) & 22.81 & 13.16 & 45 & 10 \\
Altitude (s.l.m.) & 615 & 169.22 & 840 & 360 \\
CEC (meq/100g) & 23.08 & 11.30 & 55.3 & 14.0 \\
pH & 8.08 & 0.24 & 8.31 & 7.3 \\
\hline
\end{tabular}

Tab. 4 - Shapiro and Wilks normality test of edaphic variables (original and transformed variables). (a): the normal variables selected $(\mathrm{p}>0.01)$. Untransformed variables $(X)$ have been preferably selected when possible.

\begin{tabular}{lllccc}
\hline \multicolumn{1}{c}{ Variable } & \multicolumn{1}{c}{$\mathbf{X}$} & $\sqrt{ }(\mathbf{X})$ & $\sqrt{ }(\mathbf{X}+\mathbf{0 . 5})$ & $\operatorname{Ln}(\mathbf{X}+\mathbf{1})$ & $\log (\mathbf{X})$ \\
\hline Sand (\%) & 0.0007 & 0.0007 & 0.0007 & 0.0007 & 0.0007 \\
Silt (\%) & 0.0009 & 0.0020 & 0.0019 & 0.0048 & 0.0053 \\
Clay (\%) & $0.0340^{\text {a }}$ & 0.0954 & 0.0922 & 0.1395 & 0.1427 \\
Ca (meq/100g) & 0.0070 & 0.0027 & 0.0028 & 0.0009 & 0.0009 \\
Organic matter (\%) & 0.0005 & 0.0005 & 0.0005 & 0.0005 & 0.0005 \\
Depth (cm) & 0.0014 & 0.0011 & 0.0011 & 0.0008 & 0.0008 \\
Slope (\%) & 0.0052 & $0.0132^{\text {a }}$ & 0.0129 & 0.0222 & 0.0233 \\
ALT (m.a.s.l.) & $0.0436^{\text {a }}$ & 0.0651 & 0.0651 & 0.0881 & 0.0882 \\
CEC (meq/100g) & 0.0007 & 0.0030 & 0.0029 & 0.0088 & 0.0096 \\
pH & 0.0001 & 0.0001 & 0.0001 & 0.0001 & 0.0001 \\
\hline
\end{tabular}

Tab. 5 - Pearson's correlation coefficients among edaphic variables selected as predictors.

\begin{tabular}{cllc}
\hline Variables & Clay & $\sqrt{ }$ (Slope) & ALT \\
\hline Clay & 1.0000 & -0.40276 & 0.61941 \\
$\sqrt{ }($ Slope $)$ & - & 1.00000 & -0.62665 \\
ALT & - & - & 1.0000 \\
\hline
\end{tabular}

(clay amount), in $\mathrm{pH}$ and $\mathrm{CEC}$ values. Indeed, the soils with a larger content of clays had a greater $\mathrm{CEC}, \mathrm{pH}$ values and $\mathrm{Ca}$ content. No significant differences in organic matter content were detected among the soils analyzed. To test the differences in soil properties among the above classes, one-way ANOVAs (analysis of variance) were applied and class means were compared by Tukey's test (data not shown). Variables

considered for discriminant analysis were normally distributed (Tab. 4) and weakly correlated (Tab. 5). Edaphic variables showing significant departure from normal distribution were not considered for further analysis.

Selected predictors for discriminant analysis were clay and slope (after squared root transformation) but not altitude, due its high correlation with other variables (Tab. 6).
Tab. 6 - Coefficients of the linear discriminant functions obtained for site index class estimation of Stone pine stands in Calabria (southern Italy).

\begin{tabular}{lrrr}
\hline \multirow{2}{*}{ Variables } & \multicolumn{3}{c}{ Site index class } \\
\cline { 2 - 4 } & \multicolumn{1}{c}{ I } & II & III \\
\hline Constant & -26.438 & -24.199 & -14.992 \\
Clay & 1.654 & 1.439 & 1.342 \\
$\sqrt{\text { (slope) }}$ & 6.768 & 6.766 & 4.813 \\
\hline
\end{tabular}


Tab. 7 - Error rates (\%) by site index class for the selected edaphic discriminant rule in Stone pine stands in Calabria (Italy). Error rates have been obtained by cross-validation (see text for more details).

\begin{tabular}{crrr}
\hline \multirow{2}{*}{$\begin{array}{c}\text { Actual Site } \\
\text { Index Class }\end{array}$} & \multicolumn{3}{c}{ Predicted Site Index Class } \\
\cline { 2 - 4 } & \multicolumn{1}{c}{ I } & \multicolumn{1}{c}{ II } & \multicolumn{1}{c}{ III } \\
\hline I & 33.33 & 50.00 & 16.67 \\
II & 16.67 & 50.00 & 33.33 \\
III & 0.00 & 0.00 & 100.00 \\
\hline
\end{tabular}

Plots reclassification into classes using the discriminant functions obtained showed an error rate ranging from $66.67 \%$ (class I) to 0 $\%$ (class III - Tab. 7). Overall, stands were misclassified in $38.89 \%$ of the cases using the selected predictors and the discriminant functions obtained. The pattern of relationship between the factors considered and the site productivity shows that the lower is the slope, the more important is the texture (Fig. 2) for determining the site index (SI) class. Where slope is over $35 \%$, sites are always classified in class III, while in areas with lower slope clay content strongly influences the classification of the site. Stands on calcareous soils showed no chlorotic or decay clues, but a very low growth in comparison with stands on siliceous soils (Tab. 8).

As mentioned before, the error rate using the discriminant functions obtained was lower for poorest sites. On the other hand, a low error rate is more important in the high site index classes. Errors in site index estimation for a high-productivity stands generate a higher bias in the growth and yield predictions than for a low-productivity stand. However, as our discriminant rule classify $100 \%$ of the poorest stands correctly, so it can be used to identify the worst sites to establish Stone pine plantations, helping foresters to avoid these areas as plantation sites.

\section{Discussion and conclusion}

In this study, discriminant rules useful to classify Stone pine stand productivity in $\mathrm{Ca}$ -

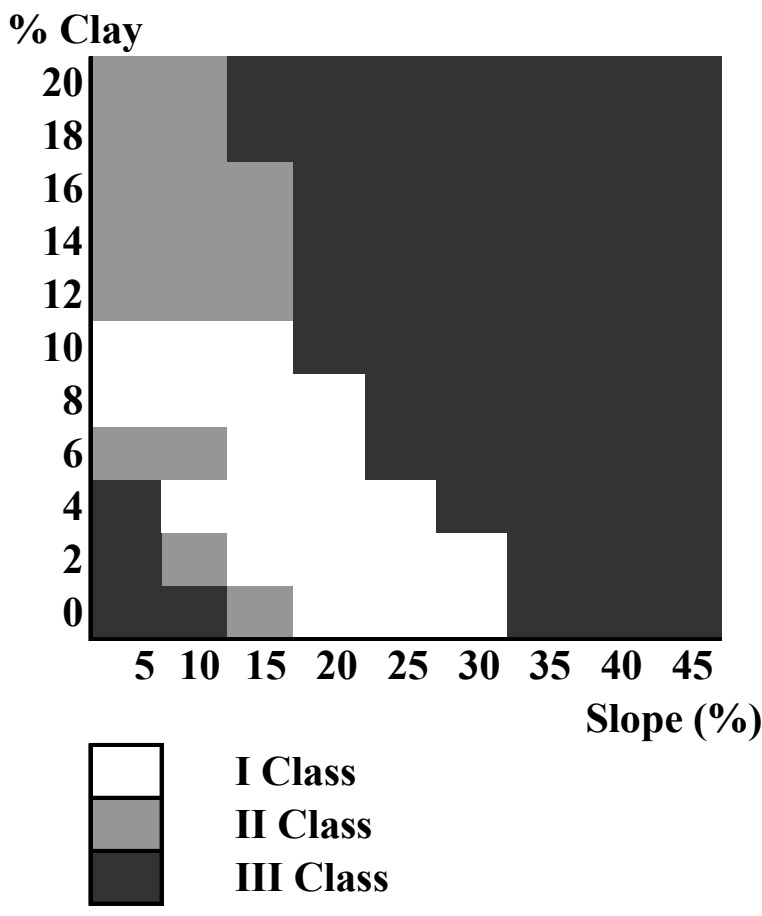

Fig. 2 - Site index classification using clay and slope as classificatory variables for Stone pine stands in Castrovillari (Calabrian Apennines, southern Italy). labria (southern Italy) have been developed. In summary, the discriminant model obtained classifies plots into the correct site index class with an overall rate of $61.11 \%$, which is considered an acceptable value for these kinds of studies.

Models based on discriminant functions using edaphic and climatic factors as site index predictors may help forest managers to classify stand productivity when information on site productivity is not available. Their use may be particularly helpful for site index assessment of young stands, where site index curves cannot be used, as well as for assessing the suitability of an area to Stone pine plantations. However, foresters should accurately plan soil analyzes needed for site index assessment, because their high costs in terms of money and time. Furthermore, some cautions have to be considered to this regards. Our study is based on soil samples from well-established forest stands, and the potential productivity of a stand planted on bare soils may be somewhat hardly evaluated using the models obtained here. Based on our results and the above considerations, priority should be given to low clay sites if there are no other limiting factors.

The use of discriminant functions allows to classify any observations based on its Euclidean distance from two or more groups of observations established a priori, using one or more predicting variables. On the other hand, discriminant analysis does not allow to determine causal relationship among productivity, soil and topographic factors. However, results from this study can help to identify patterns of relationship among soil, topographic factors and forest productivity.

Different statistical methods have been used to find relationship between these site variables and site index: discriminant analysis (Bravo \& Montero 2001, Bravo-Oviedo \& Montero 2005, tree classification models (Verbyla \& Fisher 1989), multiple regression (Wang 1995) or principal components ana-

Tab. 8 - Mean annual increment in different planted Stone pine stands in Italy. (*): Mean height.

\begin{tabular}{|c|c|c|c|c|c|c|c|c|}
\hline $\begin{array}{c}\text { Age } \\
\text { (years) }\end{array}$ & $\begin{array}{c}\mathrm{N} \\
\text { (trees/ha) }\end{array}$ & $\begin{array}{l}\text { Ho } \\
\text { (m) }\end{array}$ & $\begin{array}{c}\text { BA } \\
\left(\mathrm{m}^{2} / \mathbf{h a}\right)\end{array}$ & $\begin{array}{c}\mathbf{V} \\
\left(\mathrm{m}^{3} / \mathrm{ha}\right)\end{array}$ & $\begin{array}{c}\text { MAI } \\
\left(\mathbf{m}^{3} / \mathbf{h a}\right)\end{array}$ & Substrata & Region & Souce \\
\hline $30-40$ & - & - & - & $128-180$ & $3.6-5.6$ & sandstone & Bosco Bellia (Sicily) & Cascio 1969 \\
\hline $30-40$ & $700-500$ & $11-12.6$ & $30-32.8$ & $165-209$ & $8.2-8.7$ & sandy & Cecina (Tuscany) & Baroni 1973 \\
\hline $35-45$ & $350-190$ & - & - & $205-383$ & $4.8-7.7$ & sandy & S.Rossore (Tuscany) & Calliari et al. 1960 \\
\hline $30-40$ & $711-485$ & $12.1-13.4^{*}$ & $25.7-27.8$ & $174-228$ & $5.8-5.7$ & sandy & Feniglia (Tuscany) & La Marca 1984 \\
\hline 45 & $450-763$ & $10-12$ & $25.1-35.7$ & $162-238$ & $3.6-5.3$ & sandy & Litorale veneto (Veneto) & Del Favero et al. 1989 \\
\hline $40-50$ & $500-350$ & $12.6-14.1$ & $32.8-34.9$ & $209-247$ & $8.7-8.6$ & sandy & Cecina (Tuscany) & Baroni 1973 \\
\hline $40-50$ & $485-349$ & $13.4-14.4^{*}$ & $27.8-26.8$ & $228-249$ & $5.7-4.9$ & sandy & Feniglia (Tuscany) & La Marca 1984 \\
\hline $40-50$ & $544-752$ & $9.4-13.5^{*}$ & $17.5-42.9$ & $91-300$ & $1.7-7.5$ & granite & La Maddalena (Sardinia) & D’Autilia et al. 1967 \\
\hline $40-50$ & - & $13.7-16.1^{*}$ & - & $193-376$ & $4.8-6.5$ & sandy & Central Italy & Castellani 1989 \\
\hline $35-45-55$ & $353-877$ & $5.2-12.0$ & $10.1-44.6$ & $45.0-315.8$ & $1.0-5.7$ & calcareous & Pollino (Calabria) & Present work \\
\hline
\end{tabular}


lysis (Sanchez-Rodriguez et al. 2002).

In areas showing high silvicultural and environmental variability, the use of models for site class prediction seems more appropriate than using regression models. Verbyla \& Fisher (1989) showed the advantages of using classification methods instead of linear regression analysis when different site-index discriminant rules have been developed in the past (Harding et al. 1985, Bravo \& Montero 2001, Bravo-Oviedo \& Montero 2005). Moreover, in a highly variable environment, it is easier to assess site class than an exact site index. Our target stands in $\mathrm{Ca}$ labria show a small silvicultural variability (origin from plantation with no thinning since 20 to 30 years) and great differences in environmental conditions. In the northern temperate zone, slope is an important topographic factor influencing local site microclimate (Sariyildiz et al. 2005), as a consequence of the amount of solar radiation received. Solar radiation influences soil temperature and water availability, which in turn affect soil chemical properties. In this investigation slope and soil texture (in terms of clay) were the most relevant variables affecting site productivity.

Wang (1995) stated that: (1) many nutrients affect tree growth and the limiting nutrient(s) may vary with site; (2) there are complex interactions between nutrients not described by linear relationships; (3) chemical analysis may not give an accurate picture of nutrient availability for tree growth; and (4) usually the nutrient cycle is not considered. The site index in plain sites soils depends strongly on clay percentage. Studying Stone pine stands in southern Spain, BravoOviedo \& Montero (2005) also found a clear association between clay and poor sites, showing that the presence of clay causes bad drainage and aeration of the soil limiting the growth of this species. Our findings are in accordance with the results obtained for Stone pine stands by Boisseau (1994), Prada et al. (1997), Bravo-Oviedo \& Montero (2005) and for other Mediterranean forests by Bravo \& Montero (2001).

Bravo-Oviedo \& Montero (2005) stated that the assessment of forest productivity based on soil properties is greatly facilitated when a mature stand is located on reforested soil type, with low parental rock flow, scarce differentiation in horizons and low variability of soil attributes. Previous studies on Mediterranean forests (Bravo \& Montero 2001, Bravo-Oviedo \& Montero 2005) have stated that discriminant analysis with site variables, as texture and elevation, is appropriate in stands of Scots pine and Stone pine.

Both regional and local studies are needed in the Mediterranean basin, due to its large ecological variability, as well as to the differences in management background among the different areas. Local case studied may have great significance across the Mediterranean region, where the need of cheap and straightforward management tools may be have important fallout in forest and landscape management.

\section{References}

Baker JB, Broadfoot WM (1979). A practical field method of site evaluation for commercially important southern hardwoods. Gen. Tech. Rep. SO-26, USDA Forest Service, Southern Forest Experiment Station, New Orleans, LA, USA, pp. 51.

Baroni A (1973). Ricerche alsometriche sulle pinete di pino domestico dei tomboli di Cecina. L'Italia Forestale e Montana 28 (5): 191-197.

Boisseau B (1994). Écologie du pin pignon. Cemagref, Études Gestion des territoires. Annales Forêt 93: 173-188. - doi: 10.4267/ 2042/26753

Bouyoucos GJ (1962). Hydrometer method improved for making particle-size analyses of soils. Agronony Journal 54: 464-465. - doi: 10.2134/agronj1935.00021962002700040014x

Bravo F, Montero G (2001). Site index estimation in Scots pine (Pinus sylvestris L.) stands in the High Ebro Basin (northern Spain) using soil attributes. Forestry 74 (4): 395-406. - doi: 10.1093/ forestry/74.4.395

Bravo-Oviedo A, Montero G (2005). Site index in relation to edaphic variables in stone pine (Pinus pinea L.) stands in south west Spain. Annals of Forest Sciences 62: 61-72. - doi: 10.1051/ forest:2004086

Bray RH, Kurtz T (1945). Determination of total, organic and available forms of phosphorous in soils. Soil Science 59: 39-45. - doi: 10.1097/ 00010694-194501000-00006

Burger JA (1994). Cumulative effects of silvicultural technology on sustained forest productivity. In: "Assessing the effects of silvicultural practices on sustained productivity" (Mahendrappa MK, Simpson CM, Smith CT eds). Proceeding of the IEA/BA workshop '93, Frederickston (NB, Canada) 16-22 May 1993. Information rep. M-X191. Nat. Res. Can., Can. For. Serv., Maritimes Region, Frederickston, New Brunswick, Canada, pp. $59-70$

Calliari P, Meschini A, Quattrocchi G (1960). Piano di assestamento dei boschi della Tenuta di San Rossore per il decennio 1960-1969. Segretariato Generale della Presidenza della Repubblica, Roma, Italy.

Cascio A (1969). Tavola alsometrica del pino domestico di Bosco Bellia cresciuto in fustaia coetanea. L'Italia forestale e montana 24 (1): $67-$ 73.

Castellani C (1989). La produzione legnosa e del frutto e la durata del turno economico delle pinete coetanee di pino domestico (Pinus pinea L.) in un complesso assestato a prevalente funzione produttiva in Italia. Annali ISAFA, vol. XII, pp.161-221

D'Autilia M, Sommazzi S, Arrigoni, PV (1967). Rimboschimenti e loro risultati in Sardegna. In: Atti del Convegno "Prospettive economico-in- dutriali della produzione legnosa in Sardegna", Cagliari, Italy, pp. 79-109.

Del Favero R, De Mas G, Ferrari C, Gerdol R, Lasen C, Masutti L, De Battisti R, Paiero P, Colpi C, Urso T, Zanotto S (1989). Le pinete litorali del Veneto. Regione Veneto. Tip. Multigraf, Spinea, Venezia, Italy.

Harding RB, Grigal DF, White, EH (1985). Site quality evaluation for White Spruce plantations using discriminant analysis. Soil Science Society of America Journal 49:229-232. - doi: 10.2136/ sssaj 1985.03615995004900010046x

Helms JA (1998). The dictionary of forestry society of American Foresters. pp. 224.

Holmgren P (1994). Topographic and geochemical influence on the forest site quality, with respect to Pinus sylvestris and Picea abies in Sweden. Scand. J. For. Res. 9: 75-82. - doi: 10.1080/ 02827589409382815

Jackson ML (1958). Soil chemical analysis. Prentice-Hall Inc., Englewood Cliffs, NY, USA. Johnson DE (1998). Applied multivariate methods for data analyst. Duxbury Press, Pacific Grove, CA, USA, pp. 567.

Jokela EJ, White EH, Berglund JV (1988). Predicting Norway spruce growth from soil and topographic properties in New York. Soil Science Society of America Journal 52 (3): 809-815. doi:10.2136/sssaj1988.03615995005200030038x Kjeldalh J (1883). Neue methode zurestimmung des stickstoffs in organischen körpen. Zeitschrift fiir Analytische Chemie 22: 366-382.

La Marca O (1984). La pineta della Duna Feniglia. Ricerche sperimentali di dendrometria e di auxometria. Fasc.VIII, Istituto di Assestamento Forestale, Università di Firenze, Tip. Coppini, Firenze, Italy.

Mehlich A (1953). Rapid determination of cation and anion exchange properties and $\mathrm{pH}$ of soils. Journal of Association Agriculture Chemistry 36: 445-457.

McQuilkin RA (1976). The necessity of independent testing of soil-site equations. Soil Science Society of America Journal 40:783-785. - doi: 10.2136/sssaj1976.03615995004000050044x

Monserud RA, Moody U, Breuer DW (1990). A soil-site study for inland Douglas-fir. Canadian Journal of Forest Research 20: 686-695. - doi: 10.1139/x90-092

Morris LA, Miller RE (1994). Evidence for longterm productivity change as provided by field trials. In: "Impacts of forest harvesting on longterm site productivity" (Dyck WJ, Cole DW eds). Chapman \& Hall, New York, USA, pp. 41-80. Pacheco C (1991). Evaluating site quality of evenaged maritime pine stands in northern Portugal using direct and indirect methods. Forest Ecology and Management 41:193-204. - doi: 10.1016/0378-1127(91)90103-3

Prada MA, Gordo J, Miguel J, Mutke S, CatalánBachiller G, Iglesias S, Gil L (1997). Regiones de procedencia de Pinus pinea L. en España. Organismo Autónomo Parques Nacionales, Madrid, Spain.

Pretzsch H (2009). Forest dynamics, growth and yield. Springer, Berlin, Germany, pp. 664. 
Proe MF, Rauscher HM, Yarie J (1994). Computer simulation models and expert systems for predicting productivity decline. In: "Impacts of forest harvesting on long-term site productivity" (Dyck WJ, Cole DW eds). Chapman \& Hall, New York, USA, pp. 151-186.

Sanchez-Rodriguez F, Rodríguez-Soalleiro R, Español E, López CA, Merino A (2002). Influence of edaphic factors and tree nutritive status on the productivity of Pinus radiata D. Don plantations in northwestern Spain. Forest Ecology and Management 171:181-189. - doi: 10.1016/S0378 1127(02)00471-1

Sariyildiz T, Anderson JM, Kucuk M (2005). Effects of tree species and topography on soil chemistry, litter quality, and decomposition in northeast Turkey. Soil Biology Biochemistry 37: 1695-1706. - doi: 10.1016/j.soilbio.2005.02.004 Steinbrenner EC (1976). Factors that influence the productivity of western hemlock. Proceeding of XVI IUFRO World Congress, vol. 1, pp. 167-
185.

Switzer GL (1978). Determinants of forest stand productivity. In: Proceeding of Symposium on "Principles of maintaining productivity on prepared sites" (Tippen T ed). USDA Forest Service, Southern Region, Asheville, NC, USA, pp. 14-27.

Tsui CC, Chen ZS, Hsieh CF (2004). Relationships between soil properties and slope position in a lowland rain forest of southern Taiwan. Geoderma 123: 131-142. - doi: 10.1016/j.geoderma. 2004.01.031

Turner J, Thompson CH, Turvey ND, Hopmans P, Ryan PJ (1990). A soil technical classification system for Pinus radiata (D. Don) plantations I. Development. Australian Journal of Soil Research 28: 797-811. - doi: 10.1071/SR9900797 Verbyla DL (1986). Potential prediction bias in regression and discriminant analysis. Canadian Journal of Forest Research 16:1255-1257. - doi: $10.1139 / \mathrm{x} 86-222$
Verbyla DL, Fisher RF (1989). An alternative approach to conventional soil-site regression modeling. Canadian Journal of Forest Research 19:179-184. - doi: 10.1139/X89-025

Yimer F, Sting L, Adelkadir A (2006). Soil property variations in relation to topographic aspect and vegetation community in the south-eastern highlands of Ethiopia. Forest Ecology and Management 232: 90-99. - doi: 10.1016/j.foreco. 2006.05.055

Walkley A, Black IA (1934). An examination of the Degtjareff method for determining soil organic matter and a proposed modification of the chromic acid titration method. Soil Science 37: 29-38. - doi: 10.1097/00010694-19340100000003

Wang GG (1995). White spruce site index relation to soil, understory vegetation, and foliar nutrients. Canadian Journal of Forest Research Research 25: 29-38. - doi: 10.1139/x95-004 